\title{
SPORTUOJANČIŲ IR NESPORTUOJANČIŲ PAAUGLIŲ POŽIŪRIS İ VERTYBES IR JŲ PRASMĖS SUVOKIMĄ
}

Asta Budreikaitė, Eugenija Adaškevičienė

Klaipédos universitetas, Klaipéda, Lietuva

\begin{abstract}
Asta Budreikaitė. Socialinių mokslų (edukologijos) doktorantė. Klaipèdos universiteto Kūno kultūros katedros asistentė. Mokslinių tyrimu kryptis — dorovinès vertybès sportinèje veikloje.
\end{abstract}

\section{SANTRAUKA}

Mokslinèje literatūroje pasigendama tyrimu, kuriuose būtu analizuojamas paaugliu požiūris ì vertybes ir ju prasmès suvokimq. Vienas iš reikšmingu veiksniu, darančiu didele ịtaka paauglio vertybiniı orientaciju ir asmenybès savybiu ugdymui, yra sportine veikla.

Tyrimo tikslas — atskleisti sportuojančiu ir nesportuojančiu paangliu (5-6 klasiu mokiniu) požiūrì $\dot{z}$ vertybes ir nustatyti vertybiu prasmés suvokimo lygi.

Tyrimo uždaviniai: 1) atskleisti paaugliu požiūri ̨ terminalines ir instrumentines vertybes, ju reikšmingumo pripažinima; 2) atskleisti sportuojančiu ir nesportuojančiu paaugliu požiūri i vertybes fizinio aktyvumo aspektu; 3) nustatyti sportuojančiu ir nesportuojančiu paaugliu vertybiu prasmés suvokimo lygi.

Tyrimas atliktas 2007 m. gegužès mènesí. Buvo tiriami paaugliai (5-6 klasiu mokiniai). Paimta atsitiktine 5-6 klasiu mokiniu imtis iš aštuoniu bendrojo lavinimo mokyklu, esančiu juairiose Lietuvos kaimo vietovèse ir skirtingu dydžiu miestuose (Vilniuje, Klaipédoje) bei rajonu centruose: Plungejje, Telšiuose, Raseiniuose, Šakiuose. Imties dydis reprezentatyvus. Tiriamaja imtị sudarè 708 penktu—šeštu klasiu mokiniai: 351 (49,6\%) penktos ir $357(50,4 \%)$ šeštos klasès. Ǐs ju $485(68,5 \%)$ nesportuojantys paaugliai, kurie lankè tik kūno kultüros pamokas, ir 223 (31,5\%) sportuojantys paaugliai, lankantys sporto mokyklas ir küno kultūros pamokas. Vykdant tyrimq laikytasi etiniu ir teisiniu tyrimo principu. Kiekvienam respondentui buvo paaiškintas tyrimo tikslas ir garantuotas duomenu anonimiškumas.

Tyrimo metodai: mokslinès literatūros analizé; modifikuota M. Rokeach (1979) vertybiniu orientaciju metodika (Lee, Cockman, 1995; J. Cruz et al., 1995 ir kt.); fizinio aktyvumo grupès nustatymas (Vainiené, Kardelis, 2008); matematine statistika.

Empiriniu tyrimu nustatyta, kad šio amžiaus moksleiviai svarbiausiomis terminalinèmis vertybèmis laiko sveikata, laimingq šeimq, mokymasi, o instrumentinèmis - garbingumq ir sqžiningumq. Sportuojantiems paaugliams prioritetinès terminalinès vertybès yra: komandos veiksmu suderinamumas, žaidimo malonumas ir aktyvus gyvenimas. Nesportuojantiems mokiniams šios vertybès mažiau reikšmingos. Sportuojančiu ir nesportuojančiu paaugliu vertybiu prasmès suvokimo lygis yra panašus - reikšmingo skirtumo nenustatyta. Beveik pusè visu apklaustuju nelabai išsamiai suvokia vertybiu prasmę. Toks vertybiu prasmès suvokimas rodo, kad vertybiu iprasminimas tebèra aktuali pedagogine problema.

Raktažodžiai: požiūris ì vertybes, terminalinès ir instrumentinès vertybès, sportine veikla.

\section{IVADAS}

$\mathrm{M}$ odernèjančioje visuomenèje keičiasi požiūris i sportą ir jo vertybes. Sportinè veikla, grindžiama vertybėmis, buvo aukštinama jau senovès Graikijoje. Garbinga sportine kova, kilnumu, sąžiningumu, pagarba varžovui ir kitomis bendražmogiškomis vertybèmis grindžiama sportinè veikla formavosi ilgus šimtmečius, buvo perduodama iš kartos i kartą. Sportas, grindžiamas vertybėmis, turi ypatinga ugdomaji poveiki besiformuojančiai asmenybei, nes jis išplečia kultūros lauką: sužadina vidini nusiteikimą asmens teigiamiems sprendimams, iprasmina pozityvų elgesị konkrečioje situacijoje ir tarsi sudvasina žmogaus kūna, suteikdamas jam kitokị raiškos pavidalą.

İžymūs Lietuvos edukologai (Bitinas, 2000, 2004; Jovaiša, 2002, 2003; Martišauskienè, 2004; Aramavičiūtè, 2005) laikosi nuomonès, kad vertybiu ugdymas nèra kurios nors vienos mokomosios disciplinos uždavinys, bet turi būti integruotas i 
visų dalykų, kartu ir kūno kultūros, mokymąsi. Kūno kultūros pamokos mokykloje ir neformalusis fizinis ugdymas negali apsiriboti vien tik fiziniu galiu plètote, jis privalo brandinti asmenybę, skatinti vertybinių orientacijų ugdymą. Ugdymas be vertybių tampa ,imitacija, dresūra, kuri gali laiduoti aukštą žinių ir gebejjimų lygi, tačiau asmenybinius pokyčius gali palikti atsitiktinèje plotmejje“ (Martišauskienė, 2004).

Vertybinè orientacija, pasak V. Žemaičio (2005), yra asmens atsidavimas vertybėms, tam, kas kelia nuostabą, pagarbą, pasigèrejimą. Labai svarbu, kokias vertybes renkasi žmogus ir kokioms vertybèms jis teikia pirmenybę. Vertybinès orientacijos yra svarbiausias asmenybès struktūros komponentas. L. Jovaiša (2007) vertybinę orientaciją apibūdina kaip išugdytą sąmonès gebejjimą reguliuoti veiklą ir elgesi pagal i̇sitikinimus, dorovines normas, gyvenimo perspektyvas bei atskirti tai, kas nevertinga, priešiška asmenybès ir visuomenès gyvenime.

Kai kurie tyrejjai teigia, kad sportas, grindžiamas olimpiniais idealais, gali būti veiksminga priemonè, turinti įtakos mokinių dvasinių, dorovinių nuostatų ugdymui. S. Šukys (2001), tyrinèjęs paauglių vertybinių orientacijų formavimosi veiksnius sportine veikla, teigia, kad sportinè veikla gali turèti teigiamos itakos ne tik sportuojančiu paauglių fiziniam, bet ir jų dvasiniam tobulèjimui. Z. Krawczyk (1990), W. Brettschneider, R. Heim (1997), P. Oweis, W. L. Spinks (2001), S. J. Danish ir kt. (2003), T. A. Klomsten et al. (2004), J. A. Moreno, E. Cervello (2005) nuomone, dalyvavimas sportinèje veikloje yra vienas iš reikšmingiausių veiksnių, pozityviai veikiančių besiformuojančią paauglių vertybių sistemą, bendravimą ir bendradarbiavimą su bendraamžiais, teigiamas asmens savybes. Z. Žukowska, R. Žukovski (1998) teigia, kad „suvoktos sporto vertybès tiesiogiai veikia jauno žmogaus savižiną, savivertę, savirealizaciją, sudaro palankias sąlygas motyvacijai sportuoti“. R. Naul (2008) nuomone, olimpiniu etinių-moralinių principų, dorovinio elgesio, olimpinio sajūdžio vertybių, idealų pripažinimas bei ju taikymas sportineje veikloje turètų padèti mokiniams išmokti dorai elgtis, būti sąžiningiems ir kasdieniame gyvenime. Pasak N. M. Grendstad (1996), ypač svarbu, kokias vertybes yra išpažinęs paauglys ar kokiu vertybiu siekia, nes jo vertybiu pasirinkimas veikia ir jo elgesi. Pasak P. Karoblio (2001), sportininkas turi parodyti ne tik fizinius, intelektualinius gebèjimus, igūdžius bei mokèjimus, bet ir pademonstruoti savo asmens savybes, savo moralinius įsitikinimus, inteligentiškumą.
Mokslinèje literatūroje pažymima, kad tiriant požiūrị i vertybes atsiveria galimybè geriau pažinti paauglių vidini pasauli, atskleisti individualias vertybines orientacijas, išryškinti jų sąlyti su tiesa ir parodyti, kas jiems šiame amžiuje atrodo svarbiausia (Martišauskienė, 2004). S. Šukys (2001), tyrinèjęs paaugliu vertybinių orientacijų ugdymą sportine veikla, ir I. Smalinskaite (2003) - olimpini ugdymą, pažymi, kad paauglysteje vertybių sistema dar nèra visiškai susiformavusi ir besiformuojantys paauglio pasaulěžiūriniai idealai lemia, skatina jo veiklą bei elgesí. Todèl mūsų vertybinių orientacijų tyrimui pasirinkti paaugliai (5-6 klasių mokiniai), t. y. imliausio amžiaus moksleiviai, kuriu vertybinès orientacijos aktyviai formuojasi, o šio amžiaus vaikai yra aktyvesni nei dauguma suaugusiujų. Paauglių, kaip socialinės grupès, vertybinių orientacijų tyrimas aktualus dar ir todèl, kad jų vertybinių orientaciju ypatumai bei ugdymo optimizavimo prielaidos sportine veikla nèra žinomi. Kryptingas vertybiu ugdymas sportine veikla paskatino atlikti tyrimą, kuriuo kèlème mokslini probleminị klausimą: koks yra paauglių požiūris ị vertybes, kokias vertybes pripažista sportuojantys ir nesportuojantys paaugliai? Ar 5-6 klasių mokiniai suvokia vertybiu prasmę?

Tikètina, kad sportuojančių ir nesportuojančių paauglių vertybines orientacijas lemia ju požiūris i vertybes ir ju prasmès suvokimą.

Tyrimo objektas - sportuojančių ir nesportuojančių paauglių (5-6 klasių mokinių) požiūris i vertybes ir jų suvokimą.

Tyrimo tikslas - atskleisti sportuojančiu ir nesportuojančių paauglių (5-6 klasių mokinių) požiūrị i vertybes ir nustatyti vertybiu prasmès suvokimo lygi.

\section{Tyrimo uždaviniai:}

1. Atskleisti paauglių požiūrị i terminalines ir instrumentines vertybes, jų reikšmingumo pripažinimą.

2. Atskleisti sportuojančių ir nesportuojančių paauglių požiūrị i vertybes fizinio aktyvumo aspektu.

3. Nustatyti sportuojančiu ir nesportuojančių paauglių vertybiu prasmés suvokimo lygi.

\section{TYRIMO METODIKA}

Metodai: 1. Mokslinès literatūros analizè. 2. Empirinio tyrimo metu taikyta modifikuota M. Rokeach (1979) vertybinių orientacijų metodika (Lee, Cockman, 1995; Cruz et al., 1995), kuri leido nustatyti (tirtu paauglių) sportuojančių ir nespor- 
tuojančių respondentų požiūrị i vertybes. Pirma, respondentams buvo (pateikta) išvardyta (po) 18 terminaliniu ir instrumentiniu vertybių, kurias jie turèjo suranguoti pagal svarbą nuo 1 iki 18 vietos. Vèliau respondentų duomenys pagal reikšmingumą suskirstyti i 5 rangus (Aramavičiūtè, 2005). Jei vertybe labai svarbi - labai aukštu rangu (1-2), svarbi - aukštu (3 - 6), iš dalies svarbi - vidutiniu (7-12), nesvarbi — žemu (13-16), visiškai nesvarbi - labai žemu (17-18). Visų respondentu duomenys, remiantis vertybių svarbos ižzalgos kriterijumi, suskirstyti i tris lygius: aukšta, vidutini, žemą. Antra, iš pateiktų vertybių (terminalinių ir instrumentiniu) paaugliai turejo pasirinkti 2-3 vertybes ir išsamiai aprašyti jų turini. Anot V. Aramavičiūtès (2005), pasirinktas vertinimo kriterijus išsamus vertybiu esmès suvokimas. Respondentu atsakymai buvo sugrupuoti pagal keturis lygius: labai išsamus, išsamus, nelabai išsamus, neišsamus. Trečia, norint nustatyti fizinio aktyvumo grupę, respondentų prašyta pažymèti pirmą arba antrą grupę, kuriai jie priklauso (Vainienè, Kardelis, 2008). Pirma grupe - sportuojantys mokiniai, kurie lankè sporto mokyklą ir kūno kultūros pamokas, antra nesportuojantys paaugliai, lankantys tik kūno kultūros pamokas. Ketvirta, matematinès statistikos metodas buvo taikytas įvertinant tiriamuju požymiu absoliučių ir procentinių dažnių skaičiavimą. Taikytas aritmetinis vidurkis $(\bar{x})$, standartinis nuokrypis (S), atlikta procentinè grafinè analizè. Rodiklių skirtumas laikytas statistiškai reikšmingas, kai $p<0,05$. Tyrimo duomenims apskaičiuoti buvo naudojamas statistinès analizès paketas SPSS 12.0.
Tyrimo organizavimas. Tyrimas atliktas 2007 m. gegužès mènesí. Buvo tiriami 5-6 klasiu mokiniai, t. y. paaugliai. Tyrimui paimta atsitiktine 5-6 klasių mokinių imtis iš aštuonių bendrojo lavinimo mokyklų, esančių i̇vairiose Lietuvos kaimo vietovèse ir skirtingų dydžių miestuose (Vilniuje, Klaipėdoje) bei rajonų centruose: Plungèje, Telšiuose, Raseiniuose, Šakiuose. Imties atrankos principas - atsitiktinè lizdinè atranka, kai atsitiktinai atrenkamos klasés ir i imtị paimami visi tos klasès mokiniai. Iš 720 išdalytų anketų tinkamai užpildytos buvo 708. Imties dydis reprezentatyvus. Penktos klasės mokinių buvo 351 (49,6\%), šeštos - 357 (50,4\%). Iš jų 485 (68,5\%) nesportuojantys paaugliai, kurie lankè tik kūno kultūros pamokas, ir $223(31,5 \%)$ sportuojantys paaugliai (lankè sporto mokyklą ir kūno kultūros pamokas). Vykdant tyrimą laikytasi etiniu ir teisiniu tyrimo principu. Kiekvienam respondentui buvo paaiškintas tyrimo tikslas ir garantuotas duomenu anonimiškumas.

\section{REZULTATAI}

Tyrimo duomenys padejo nustatyti, kurios terminalinès vertybès $5-6$ klasių mokiniams yra pačios svarbiausios (aukštas lygis), kurios mažiau svarbios (vidutinis lygis) ar visiškai nesvarbios (žemas lygis) (žr. 1 lent.).

Daugiau nei pusè apklaustų mokinių pačiomis svarbiausiomis terminalinėmis vertybėmis laiko sveikatą (79,8\%), laimingą šeimą (79,7\%). Šias vertybes paaugliai įvertino aukščiausiu rangu.

\begin{tabular}{|l|c|c|c|c|}
\hline $\begin{array}{r}\text { Vertybių svarbumo } \\
\text { lygiai, \% }\end{array}$ & Aukštas & Vidutinis & Žemas & $\begin{array}{c}\text { Vieta pagal } \\
\text { svarbumą }\end{array}$ \\
\hline Aertybės & 44,5 & 39,3 & 16,3 & 12 \\
\hline Rüpinimasis kitais & 32,5 & 43,5 & 24,0 & 17 \\
\hline Grožis & 22,6 & 31,6 & 45,8 & 18 \\
\hline Komandos veiksmų suderinamumas & 54,0 & 33,8 & 12,3 & 7 \\
\hline Laimėjimas / pergalė & 43,5 & 31,2 & 25,3 & 13 \\
\hline Gebėjimų rodymas & 37,1 & 44,2 & 18,7 & 15 \\
\hline Laiminga šeima & 79,7 & 14,3 & 6,0 & 2 \\
\hline Laisvė & 50,8 & 34,2 & 15,1 & 11 \\
\hline Lygybė & 52,7 & 33,5 & 13,9 & 8 \\
\hline Žaidimo malonumas & 52,3 & 33,3 & 14,4 & 9 \\
\hline Taika & 62,7 & 29,5 & $7,7 \%$ & 4 \\
\hline Patogus gyvenimas & 42,5 & 32,9 & 24,5 & 14 \\
\hline Mokymasis & 66,8 & 22,0 & 11,3 & 3 \\
\hline Savigarba & 51,3 & 36,0 & 12,7 & 10 \\
\hline Pripažinimas & 32,9 & 43,8 & 23,3 & 16 \\
\hline Sveikata & 79,8 & 16,0 & 4,2 & 1 \\
\hline Tikri draugai & 58,9 & 33,9 & 7,2 & 6 \\
\hline Pasitikejimas savimi & 62,4 & 28,0 & 9,6 & 5 \\
\hline
\end{tabular}

1 lentelè. 5-6 klasių mokinių terminalinių vertybių reikšmingumo pripažinimas 
2 lentelè. 5-6 klasių mokinių instrumentinių vertybių reikšmingumo pripažinimas

\begin{tabular}{|l|c|c|c|c|}
\hline $\begin{array}{r}\text { Vertybių svarbumo } \\
\text { lygiai, } \%\end{array}$ & Aukštas & Vidutinis & Žemas & $\begin{array}{c}\text { Vieta pagal } \\
\text { svarbumą }\end{array}$ \\
\hline Lydertybės & 34,7 & 31,0 & 34,3 & 15 \\
\hline Darbštumasimas & 53,1 & 37,4 & 9,5 & 3 \\
\hline Tvarkingumas & 39,7 & 36,7 & 23,5 & 14 \\
\hline Drąsa & 33,3 & 37,0 & 29,7 & 17 \\
\hline Geranoriškumas & 46,6 & 37,3 & 16,1 & 9 \\
\hline Naudingumas kitiems & 26,1 & 33,9 & 40,0 & 18 \\
\hline Garbingumas & 57,2 & 33,6 & 9,2 & 1 \\
\hline Džiaugsmas & 49,2 & 35,7 & 15,2 & 6 \\
\hline Kilnumas & 40,4 & 40,4 & 19,2 & 13 \\
\hline Tvirta valia & 48,7 & 37,7 & 13,6 & 7 \\
\hline Atkaklumas & 34,6 & 45,9 & 19,5 & 16 \\
\hline Sąžiningumas & 55,9 & 33,2 & 10,8 & 2 \\
\hline Jautrumas & 44,6 & 38,6 & 16,8 & 12 \\
\hline $\begin{array}{l}\text { Tarpusavio priklausomybe } \\
\text { komandoje }\end{array}$ & 44,6 & 43,2 & 12,1 & 11 \\
\hline Paklusnumas & 50,7 & 35,6 & 13,7 & 5 \\
\hline Mandagumas & 47,2 & 38,3 & 14,5 & 8 \\
\hline Atsakingumas & 52,5 & 35,7 & 11,7 & 4 \\
\hline Savikontrole & 46,3 & 39,3 & 14,4 & 10 \\
\hline
\end{tabular}

Kai kurie paaugliai svarbiomis vertybèmis pasirinko mokymąsi $(66,8 \%)$, pasitikejjimą savimi $(62,4 \%)$ ir tikrus draugus $(58,9 \%)$. Mažiau kaip pusè penktoku ir šeštoku svarbiomis vertybemis laikè aktyvu gyvenimą (44,5\%), laimèjimą / pergalę $(43,5 \%)$. Prie nereikšmingiausiu vertybiu priskiriamas grožis $(22,6 \%)$, kuris buvo ịvertintas žemiausiu rangu. Taigi terminalinių vertybių viršūnejje yra sveikata, laiminga šeima, mokymasis, taika, pasitikejjimas savimi. Tai geras rodiklis, tačiau ne itin didelis noras būti pripažintu visuomenès (mokyklos bendruomenès), per mažas dèmesys rūpinimuisi kitu žmogumi ir menkas grožio pripažinimas gali sukelti kliūčiu igyvendinant šias vertybes.

Išanalizavus instrumentinių vertybių pasiskirstymą pagal svarbumo pripažinimo kriterijų paaiškèjo, kad aukščiausiu lygiu išskirtas garbingumas (57,2\%) (žr. 2 lent.).

Šiek tiek mažiau moksleivių vertinamas sąžiningumas $(55,9 \%)$, darbštumas $(53,1 \%)$, atsakingumas $(52,5 \%)$ ir paklusnumas $(50,7 \%)$. Dar mažiau paaugliai vertina tvirtą valią, mandagumą, geranoriškumą ir savitvardą. Tyrimo duomenu analizė teikia pagrindą manyti, kad menkas kai kurių vertybių pripažinimas gali tapti realiu trukdžiu praktiškai igyvendinti terminalines vertybes. Sunkumų gali patirti apie ketvirtadalis respondentų, nes būti naudingu kitiems jų gyvenime nèra prioritetine vertybe். Taip pat atkaklumo ir drąsos, kaip vertybiu svarbumo gilesnès ižvalgos, stoka orientuoja pedagogus didesni dèmesi kreipti $\mathfrak{i}$ vertybių prasmès suvokimo pagilinimą, nes šios vertybės itin aiškiai pasireiškia ir funkcionuoja sportineje veikloje.

Lyginamoji tyrimo duomenų analizė atskleidè kai kuriuos reikšmingus sportuojančių ir nesportuojančių paauglių požiūrio į vertybes skirtumus. Iš 3 lentelejje pateiktų duomenų matyti, kad kuo aritmetinis vidurkis arčiau vieneto (pvz.: $\bar{x}=$ 1,51 ), tuo vertybè svarbesnè (ypač svarbi) paaugliui. Statistiškai reikšmingi skirtumai susiję su šiomis terminalinėmis vertybėmis: aktyviu gyvenimu, gebėjimų rodymu, komandos veiksmu suderinamumu, laimejjimu / pergale ir žaidimo malonumu (žr. 3 lent.).

Sportuojantiems paaugliams labiau negu nesportuojantiems svarbios šios terminalinès vertybės: komandos veiksmų suderinamumas $(1,51 \pm$ $0,72)$, žaidimo malonumas $(1,53 \pm 0,77)$ ir aktyvus gyvenimas $(1,54 \pm 0,74)$. Komandos veiksmu suderinamumas $(1,63 \pm 0,75)$ bei žaidimo malonumas $(1,77 \pm 0.96)$ taip pat reikšmingos vertybès ir nesportuojantiems mokiniams. Abieju grupių paaugliams mažiausiai reikšminga terminalinè vertybè - laimejjimas / pergalè. Lygindami duomenis fizinio aktyvumo aspektu pastebejome, kad abiejų grupių paaugliai ypač svarbias ir visiškai jiems nesvarbias terminalines vertybes išskyrè labai panašiai, tik visos šios vertybès reikšmingesnès sportuojantiems nei nesportuojantiems.

Taip pat buvo analizuotas sportuojančių ir nesportuojančių paauglių požiūris ị instrumentines vertybes (žr. 4 lent.).

Sportuojančių paauglių požiūrio i̇ instrumentines vertybes duomenų sklaidos analizè parodè, 


\begin{tabular}{|c|c|c|c|}
\hline Terminalinès vertybès & Paauglių grupės & $\begin{array}{c}\text { Aritmetinis } \\
\text { vidurkis }(\bar{x}), \\
\text { st. nuokrypis (S) }\end{array}$ & $\mathbf{p}$ \\
\hline \multirow{2}{*}{ Aktyvus gyvenimas } & Sportuojantys & $1,54 \pm 0,74$ & \multirow{2}{*}{0,000} \\
\hline & Nesportuojantys & $1,88 \pm 0,89$ & \\
\hline \multirow{2}{*}{ Gebėjimų rodymas } & Sportuojantys & $1,70 \pm 0,76$ & \multirow{2}{*}{0,000} \\
\hline & Nesportuojantys & $1,95 \pm 0,89$ & \\
\hline \multirow{2}{*}{ Komandos veiksmų suderinamumas } & Sportuojantys & $1,51 \pm 0,72$ & \multirow{2}{*}{0,044} \\
\hline & Nesportuojantys & $1,63 \pm 0,75$ & \\
\hline \multirow{2}{*}{ Laimejjimas / pergalè } & Sportuojantys & $1,73 \pm 0,92$ & \multirow{2}{*}{0,000} \\
\hline & Nesportuojantys & $2,03 \pm 1,09$ & \\
\hline \multirow{2}{*}{ Žaidimo malonumas } & Sportuojantys & $1,53 \pm 0,77$ & \multirow{2}{*}{0,001} \\
\hline & Nesportuojantys & $1,77 \pm 0.96$ & \\
\hline
\end{tabular}

3 lentelè. Sportuojančių ir nesportuojančių paauglių požiūris ị terminalines vertybes

\begin{tabular}{|c|c|c|c|}
\hline Instrumentinės vertybės & Paauglių grupės & $\begin{array}{c}\text { Aritmetinis } \\
\text { vidurkis }(\bar{x}), \\
\text { st. nuokrypis (S) }\end{array}$ & $\mathbf{p}$ \\
\hline \multirow{2}{*}{ Atkaklumas } & Sportuojantys & $1,79 \pm 0,90$ & \multirow{2}{*}{0,007} \\
\hline & Nesportuojantys & $1,98 \pm 0,87$ & \\
\hline \multirow{2}{*}{ Atsakingumas } & Sportuojantys & $1,73 \pm 0,81$ & \multirow{2}{*}{0,033} \\
\hline & Nesportuojantys & $1,59 \pm 0,80$ & \\
\hline \multirow{2}{*}{ Darbštumas } & Sportuojantys & $1,44 \pm 0,67$ & \multirow{2}{*}{0,000} \\
\hline & Nesportuojantys & $1,65 \pm 0,74$ & \\
\hline \multirow{2}{*}{ Drąsa } & Sportuojantys & $1,84 \pm 0,96$ & \multirow{2}{*}{0,000} \\
\hline & Nesportuojantys & $2,20 \pm 1,04$ & \\
\hline \multirow{2}{*}{ Geranoriškumas } & Sportuojantys & $1,90 \pm 1,01$ & \multirow{2}{*}{0,015} \\
\hline & Nesportuojantys & $1,71 \pm 0.88$ & \\
\hline \multirow{2}{*}{ Lyderiavimas } & Sportuojantys & $1,89 \pm 1,00$ & \multirow{2}{*}{0,000} \\
\hline & Nesportuojantys & $2,28 \pm 1,16$ & \\
\hline \multirow{2}{*}{ Paklusnumas } & Sportuojantys & $1,55 \pm 0,72$ & \multirow{2}{*}{0,006} \\
\hline & Nesportuojantys & $1,73 \pm 0,87$ & \\
\hline \multirow{2}{*}{ Tarpusavio priklausomybė } & Sportuojantys & $1,63 \pm 0,67$ & \multirow{2}{*}{0,037} \\
\hline & Nesportuojantys & $1,76 \pm 0,86$ & \\
\hline
\end{tabular}

4 lentelè. Sportuojančių ir nesportuojančių paauglių požiūris ị instrumentines vertybes kad pirmoje vietoje yra darbštumas $(1,44 \pm 0,67)$, antroje - paklusnumas, t. y. susitarimu laikymasis sporto varžybose $(1,55 \pm 0,72)$ ir trečioje - tarpusavio priklausomybė komandoje $(1,63 \pm 0,67)$. Nereikšmingomis instrumentinèmis vertybèmis laikomas geranoriškumas $(1,90 \pm 1,01)$, lyderiavimas $(1,89 \pm 1,00)$ ir drąsa $(1,84 \pm 0,96)$.

Nesportuojantys paaugliai labiausiai vertina atsakingumą $(1,59 \pm 0,80)$ ir darbštumą $(1,65$ $\pm 0,74)$, bet mažiausiai svarbiomis vertybèmis laiko lyderiavimą $(2,28 \pm 1,16)$, drąsą $(2,20$ $\pm 1,04)$ ir atkaklumą $(1,98 \pm 0,87)$. Vertindami sportuojančių ir nesportuojančių paauglių požiūri $i$ instrumentines vertybes pastebejome, kad svarbiausia jiems darbštumo vertybė. Sportuojantiems paaugliams ši vertybė yra pirmoje vietoje, o nesportuojantiems - antroje. Palyginus sportuojančių ir nesportuojančiu mokiniu požiūrị i, jų nuomone, nereikšmingas instrumentines vertybes buvo nustatyta, kad lyderiavimas svarbesnis sportuojantiems paaugliams nei nesportuojantiems.

Tyrimu buvo siekta ne tik išsiaiškinti, kokias vertybes paaugliai labiau vertina, bet ir kaip jie suvokia šiu vertybiu prasmę (1 pav.). Vertybių (terminaliniu ir instrumentinių) prasmès suvokimas rodo paaugliu sąmoningumą ir sudaro prielaidas atitinkamai elgtis sportinèje veikloje.

Iš tyrimo rezultatų matyti, kad visiems paaugliams būdingas nelabai išsamus vertybių suvokimas. Dauguma $(45,2 \%)$ respondentų netiksliai, paviršutiniškai ir net klaidingai suprato kai kurias vertybes. Jie išskirdavo tik vieną kuri nors jų požymį arba iš viso neteisingai apibūdindavo jų turini. Todèl galima teigti, kad daugumai paaugliu sunku suvokti vertybiu prasmę. Palyginus sportuojančiu ir nesportuojančių paauglių vertybių prasmés suvokimą statistiškai reikšmingo skirtumo nenustatyta. Statistiškai reikšmingu skirtumų aptikta tarp 5 ir 6 klasès mokinių suvokimo (2 pav.).

Šeštos klasės mokiniai geriau negu penktokai suvoke terminalinių ir instrumentiniu vertybiu prasmę, nes apie penktadali vertybiu $(21,8 \%)$ jie aprašè išsamiai. Toks vertybiu prasmès suvokimas rodo, kad šeštokai brandesni $(p=0,007)$ nei penktokai. 
1 pav. Paauglių vertybių prasmès suvokimas

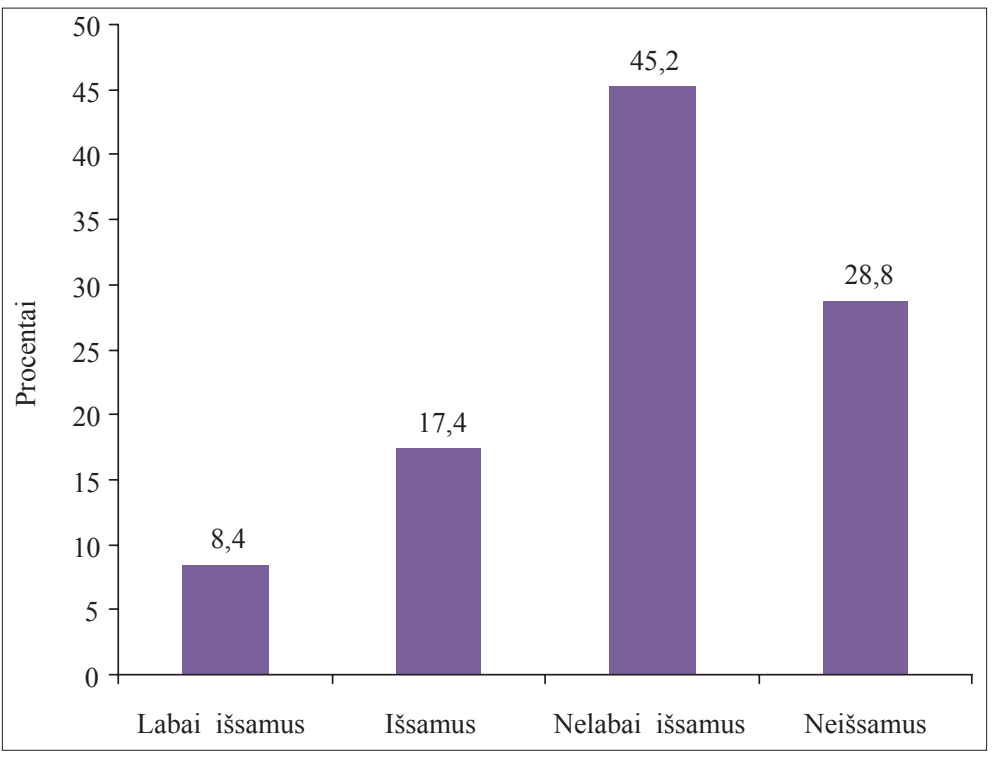

2 pav. 5-6 klasių mokinių vertybių prasmès suvokimas

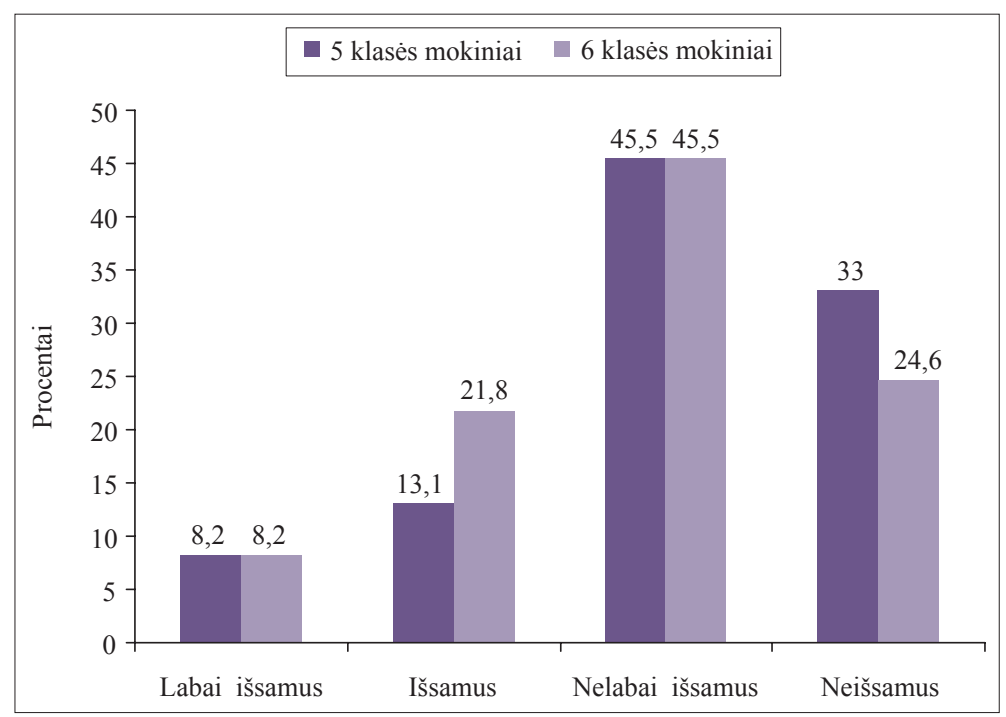

\section{REZULTATŲ APTARIMAS}

D. Simmons ir R. Dickinson (1986) vieni iš pirmuju pradejjo tyrinèti vertybių reikšmę sportinejje veikloje pagal M. Rokeach metodiką. Poreikis tirti atsirado dèl kylančių prieštaravimų, konstatuojamu teorijoje ir pasireiškiančių praktikoje, t. y. realybèje (Šukys, 2002). Literatūroje dar stokojama duomenu apie sportuojančiu ir nesportuojančių paauglių požiūrị i vertybes, tyrimo metu taikant M. Rokeach metodiką. Mūsų empiriniu tyrimu siekta nustatyti bei i̇vertinti sportuojančių ir nesportuojančių paaugliu (5-6 klasių mokiniu) požiūrị i vertybes ir jų prasmès suvokimą. Gauti rezultatai rodo, kad visiems paaugliams (5-6 klasių) svarbiausios terminalinès vertybès yra sveikata, laiminga šeima, mokymasis, o instrumentinès - garbingumas ir sąžiningumas, kurios respondentų išskirtos aukštu lygiu. Žemiausiu lygmeniu pažymètos mažiausiai reikšmingos vertybès - grožis, rūpinimasis kitais žmonemmis, naudingumas kitiems ir drąsa. Panašias išvadas daro ir kiti autoriai (Šukys, 2001; Smalinkaitè, 2003; Martišauskienè, 2004; Aramavičiūtè, 2005; Barzdžiukienè, 2006; Verbylaitè, 2006), kurių tyrimai parodè, kad daugumai paauglių būdingos aukštu lygiu išskirtos vertybès - sveikata, laiminga šeima, draugai, savigarba, laisve, viskuo aprūpintas gyvenimas ir kt. Galima manyti, kad 5-6 klasiu mokiniams itin svarbios paauglystès laikotarpiu būdingos vertybès.

Tyrimo duomenų lyginamoji analizé parodè, kad sportuojantiems paaugliams labiau nei nesportuojantiems svarbesnès yra šios terminalinès vertybės: komandos veiksmų suderinamumas, žaidimo malonumas ir aktyvus gyvenimas. Tiek sportuojantiems, tiek nesportuojantiems paaugliams labai svarbios ir nesvarbios terminalinès vertybės yra labai panašios. Pabrèžtina, kad visos minètos vertybės reikšmingesnès sportuojantiems negu nesportuojantiems paaugliams.

Analizuodami sportuojančiu ir nesportuojančių paauglių požiūrị $\mathfrak{i}$ instrumentines vertybes 
nustatėme, kad reikšmingiausia jiems yra darbštumo vertybé, tačiau sportuojantiems paaugliams ši vertybė yra svarbesné nei nesportuojantiems. Fiziškai aktyviems paaugliams nereikšmingos instrumentinès vertybès yra geranoriškumas, lyderiavimas ir drąsa, o nesportuojantiems - lyderiavimas, drąsa ir atkaklumas. E. Martišauskienè (2004), L. D. Barzdžiukienè (2006) nurodo, kad paaugliams ne itin patrauklios tokios vertybès kaip drąsa, tvarkingumas. M. Zacharovas (Захаров, 2002) teigia, kad sportuojantiems paaugliams labai svarbios vertybès yra mokymasis, darbštumas, mažiausiai svarbios - lyderiavimas ir grožis.

Pasak V. Aramavičiūtès (2005), aukštesnis kognityvinis lygmuo pasiekiamas tik tada, kai mokinys suvokia vertybes ir jas iprasmina. Minètos autorès atlikti vertybiu esmès suvokimo tyrimai parodè, kad vyresnių klasių mokiniai nelabai išsamiai apibūdino vertybių turini. Mokslininkès vertybiu esmès suvokimo tyrimo kai kurie duomenys pagal vertinimo kriterijus sutampa su mūsu gautaisiais. Tiek sportuojantys, tiek nesportuojantys paaugliai nelabai išsamiai gebejo aprašyti vertybių turini, paaiškinti jų esmę. Mūsų tyrimo rezultatai parodè, kad paauglių vertybių prasmès suvokimas tiek lyties, tiek fizinio aktyvumo aspektu labai panašūs.

Apibendrindami tyrimo rezultatus galime teigti, kad beveik pusé visu paauglių nelabai suvokia vertybiu prasmę. Vertybiu prasmès suvokimas ir ju iprasminimas vis dar tebèra aktuali pedagogine problema. Formuluotina prielaida, kad atkalumo, drąsos, vertybių svarbos nepripažinimas gali lemti jų raišką sportinejje veikloje ir jų iprasminimą gyvenime. Be to, vertybių suvokimas gali būti susijęs su 5-6 klasių mokinių amžiaus ypatybèmis, nes vertybinès orientacijos paauglystejje dar tik formuojasi.

\section{IŠVADOS}

1. Paauglių vertybinès orientacijos dar tik formuojasi, vertybių prasmès įžvalgos sietinos su požiūrio i jas gilinimu, jų iprasminimu. Šio amžiaus moksleiviai svarbiausiomis terminalinėmis vertybèmis laiko sveikata, laimingą šeima, mokymąsi, instrumentinèmis - garbingumą ir sąžiningumą. Mažiausiai reikšmingomis vertybèmis paaugliai laiko grožĭ, rūpinimąsi kitais žmonėmis ir naudingumą kitiems. Žemiausiu lygmeniu ivvardija drąsą.

2. Sportuojančiu ir nesportuojančių mokinių požiūrio i̇ vertybes tyrimai atskleide, kad sportuojantieji labiau linkę pripažinti darbštumą, komandos veiksmų suderinamumą, žaidimo malonumą ir aktyvų gyvenimą. Nesportuojantys paaugliai nesvarbiomis vertybėmis laiko lyderiavimą, o sportuojantys - geranoriškuma.

3. Beveik pusè visu paauglių nelabai suvokia vertybių prasmę. Toks nelabai išsamus ir neišsamus vertybiu prasmès suvokimas rodo, kad visiems paaugliams (tiek sportuojantiems, tiek nesportuojantiems) būdingas neaukštas vertybių internalizacijos kognityvinis lygmuo.

\section{LITERATŪRA}

Aramavičiūtè, V. (2005). Auklëjimas ir dvasinè asmenybès branda. Vilnius: Gimtasis žodis.

Barzdžiukienė, L., D. (2006). Studento asmenybės kultūrinio ir dorovinio ugdymo veiksniai. Asmenybe ir kultūra: moksliniu straipsniu rinkinys. Vilnius: Technika.

Bitinas, B. (2004). Hodegetika: auklejimo teorija ir technologija. Vilnius: Kronta.

Bitinas, B. (2000). Ugdymo filosofija. Vilnius: Enciklopedija.

Brettschneider, W., Heim, R. (1997). Identity, Sport, and Youth Development. The Physical Self: From Motivation to Wel-Being. Champaign, IL: Human Kinetics Publishing.

Cruz, J., Baixados, M., Valiente, L., Capdevila, L. (1995). Prevalent values in young Spanish soccer players. International Review of the Sociology of Sport, $30(3 / 4)$, $353-368$

Danish, S. J., Taylor, E. T., Fazio, R. J. (2003). Enhancing adolescent development through sports and leisure. Handbook of Development Psychology: Blackwell Handbook of Adolescence. Blackwell Publishing.

Grendstad, N. M. (1996). Mokytis - tai atrasti: susiliejančio ugdymo principai ir praktiniai darbo būdai. Vilnius: Margi raštai.

Jovaiša, L. (2002). Edukologijos ǰvadas. Vilnius: Vilniaus universiteto leidykla.

Jovaiša, L. (2007). Enciklopedinis edukologijos žodynas. Vilnius: Gimtasis žodis.

Jovaiša, L. (2003). Hodegetika. Vilnius: Agora.

Karoblis, P. (2001). Didelio meistriškumo sportininku rengimo problemos. Sporto mokslas, 2 (24), 2 -7.

Klomsten, T. A., Skaalvik, E. M., Espness, A. G. (2004). Physical self-concept and sports: Do gender differences still exsist? Journal of Research [žiūrèta 2009-02-16]. Prieiga internetu: http://www.findarticles.com/p/articles/ mi m224/is 12 50/ai 113419430

Krawczyk, Z. (1990). Sport and Humanism. Aspects of an Analysis: World Congress of Sociology, Spain, 9-13 July.

Lee, M., Cockman, M. (1995). Values in children's sport: Spontaneously expressed values among young athletes. International Review of the Sociology of Sport, $30(3 / 4)$, $337-348$.

Martišauskienè, E. (2004). Paaugliu dvasingumas kaip pedagoginis reiškinys: monografija. Vilnius: VPU leidykla. P. 136.

Moreno, J. A., Cervello, E. (2005). Physical self-perseption in Spanish adolescents: Effects of gender and involvent in physical activity. Journal of Human Movement Studies, $48,291-311$.

Naul, R. (2008). Olympic pedagogy as a theory of deve- 
lopment of ethical and humanistic values in education. Sporto mokslas, 3 (53), 9-15.

Oweis, P., Spinks, W. L. (2001). Psychological outcomes of physical activity: A theoretical perspective. Journal of Human Movement Studies, 40, 351-375.

Rokeach, M. (1979). Understanding Human Values. New York, London: The Free Press.

Simmons, D. D., Dickinson, R. V. (1986). Measurement of values expression ir sports and athletics. Perceptual and Motor Skills, 62, 651-658.

Smalinskaite, I. (2003). Moksleiviu olimpinis ugdymas kaip pedagogine sistema: daktaro disertacijos santrauka. Vilnius: VPU leidykla.

Šukys, S. (2002). Socialiniai, moraliniai sporto sociologijos aspektai. Kaunas: LKKA.

Šukys, S. (2001). Sportinè veikla, kaip paaugliu vertybi- niu orientaciju, asmenybès savybiu ir socialinio elgesio formavimosi veiksnys: edukologijos daktaro disertacija. Kaunas: LKKA.

Vainienè, E., Kardelis, K. (2008). Jaunimo mokyklų moksleivių fizinio aktyvumo sąsajos su mokymosi motyvacija, savigarba ir socialine integracija. Ugdymas. Küno kultūra. Sportas, 1 (68), 100-107.

Verbylaite, D. (2006). Dvasingumas ir jo ugdymo galimybès universitete. Šiauliai: Šiauliu universiteto leidykla.

Žemaitis, V. (2005). Etikos žodynas. Vilnius: Rosma.

Žukowska, Z., Žukovski, R. (1998). Universaliosios olimpinio ugdymo vertybės alternatyvaus ugdymo programose. Sporto mokslas, 4 (13), 13-16.

Захаров, М. (2002). Фэйр плей в системе олимпийского образования: автореферат диссертации. Смоленск. C. 16 .

\title{
VALUE ATTITUDES AND PERCEPTION OF ADOLESCENTS ENGAGED AND NOT ENGAGED IN SPORTS
}

\author{
Asta Budreikaitė, Eugenija Adaškevičienė \\ University of Klaipéda, Klaipéda, Lithuania
}

\begin{abstract}
The scientific literature still lacks studies, which analyze adolescents' attitudes towards values and perception of their conception. One of the major factors making a significant impact on adolescents' value orientations and their personality development is sporting activity. The aim of the research was to determine and evaluate value attitudes and perception of adolescents engaged and not engaged in sports. The tasks of the research were:

1. To reveal adolescents' attitudes towards terminal and instrumental values and the acknowledgment of their significance.

2. To unfold attitudes towards values from the perspective of physical activity.

3. To determine the level of perception of value meaningfulness of adolescents engaged and not engaged in sports.

The research was carried out in May 2007. The respondents were adolescents (5-6th formers). The sample of the research was randomly chosen among 5-6th formers from eight secondary schools of different rural areas of Lithuania and different cities (Vilnius, Klaipeda) and regional centers (Plungè, Telšiai, Raseiniai, Šakiai). The size of the sample consisted of 708 schoolchildren. $351(49.6 \%)$ of them were $5^{\text {th }}$-formers and $357(50.4 \%)$ $6^{\text {th }}$-formers. $485(68.5 \%)$ among them were not engaged in sports and they only attended the lessons of physical training, and $223(31.5 \%)$ were engaged in sports and attended sports schools and the lessons of physical training. In the process of the research ethical and legal principles were observed. The aim of the research was explained to every respondent and the anonymity of the research was guaranteed.

Methods of the research: the analysis of scientific literature; modified M. Rokeach (1979) methodology of value orientations (Cruz et al., 1995; Lee, Cockman, 1995); physical activity group setting (Vainienè, Kardelis, 2008); mathematical statistics.

The empirical study showed that adolescents of that age considered health, happy family and learning to be the most relevant terminal values, and instrumental values were respectfulness and honesty. Adolescents engaged in sports gave priority to the terminal values with compatibility of team activities, game enjoyment and active life, whereas respondents not engaged in sports considered these values to be less significant. The level of perception of the notion of values among adolescents engaged and not engaged in sports was similar statistically significant differences were not found. Almost half of all adolescents surveyed did not fully perceive the notion of values. Such incomprehensive level of perception of the notion of values shows that deepening insight into the values notion still remains a relevant pedagogical problem.
\end{abstract}

Keywords: attitude towards values, terminal and instrumental values, sporting activity.

Gauta 2009 m. balandžio 6 d.

Received on April 6, 2009

Priimta $2010 \mathrm{~m}$. vasario $4 \mathrm{~d}$.

Accepted on February 4, 2010
Asta Budreikaitė

Klaipedos universitetas

(Klaipeda University)

S. Nëries g. 5, LT-92227 Klaipèda

Lietuva (Lithuania)

$\mathrm{Tel}+37061220711$

E-mail asta.budreikaite@gmail.com 